\title{
Widespread Inverted Papilloma in the Frontal Sinus Treated by Unilateral Osteoplastic Flap Surgery without Obliteration
}

\author{
Ki Ju Cho ${ }^{1}$, Hyun-Jin Cho ${ }^{1,2}$, Sea-Yuong Jeon ${ }^{1,2,3}$, and Sang-Wook Kim ${ }^{1,2,3}$ \\ Department of Otorhinolaryngology, ${ }^{1}$ Gyeongsang National University Hospital, ${ }^{2}$ Institute of Health Sciences, \\ Gyeongsang National University, ${ }^{3}$ Gyeongsang National University College of Medicine, Jinju, Korea
}

\section{전두동 폐쇄술 시행 없이 일측 골성형 피판술로 치유한 반전성 유두종 1예}

\author{
조기주 ${ }^{1} \cdot$ 조현진 ${ }^{1,2} \cdot$ 전시영 ${ }^{1,2,3} \cdot$ 김상욱 ${ }^{1,2,3}$ \\ 경상대학교병원 이비인후과학교실, ${ }^{1}$ 경상대학교 건강과학연구원, ${ }^{2}$ 경상대학교 의과대학 이비인후과학교실 ${ }^{3}$
}

\author{
Received December 7, 2016 \\ Revised February 14, 2017 \\ Accepted February 24, 2017 \\ Address for correspondence \\ Sang-Wook Kim, MD, PhD \\ Department of Otorhinolaryngology, \\ Gyeongsang National \\ University Hospital, \\ 79 Gangnam-ro, Jinju 52727, Korea \\ Tel $+82-55-750-8177$ \\ Fax +82-55-759-0613
}

E-mail astroflower77@hanmail.net
Inverted papilloma is a rare sinonasal tumor that mainly occurs in adults during the 5 th decade. Three characteristics make this tumor very different from other sinonasal tumors: a relatively strong potential for local destruction, high rate of recurrence, and a risk of carcinomatous evolution. Etiology remains little understood, but an association with human papilloma virus has been reported in up to $40 \%$ of cases, raising the suspicions of implication in the pathogenesis of inverted papilloma. Treatment of choice is surgery, by endonasal endoscopic or external approach, depending on extension and tumoral characteristics. We experienced a case of 42-yearold male with inverted papilloma which originated from the ethmoid roof and spread into the frontal sinus. He was treated successfully by unilateral osteoplastic flap surgery without obliteration, and we report on the treatment of this case, along with a review of literature.

Korean J Otorhinolaryngol-Head Neck Surg 2018;61(9):478-84

Key Words Frontal sinus · Papilloma, inverted · Surgical procedures, operative.

\section{서 론}

반전성 유두종은 비부비동에 발생하는 종양의 $0.4 \sim 7 \%$ 를 차지하며, 10 만 명당 0.2 명에서 1.5 명의 유병률을 가진다. ${ }^{1)}$ 모 든 연령층에서 발생할 수 있으나 40 60대 사이에 호발하며, 남자에게 더 많이 발생하는 것으로 알려져 있다. 임상증상은 종양의 위치, 범위, 진행정도 등에 따라 다양하며, 비폐색, 비 루, 후각소실, 비출혈 등이 나타난다. ${ }^{2)}$ 국소적 침습성으로 인 해 주위조직을 파괴하며, 치료 후 재발률이 높고, 약 $10 \%$ 전후 에서 악성으로 전환하는 임상적 특징이 있어 다른 종양과 구

This is an Open Access article distributed under the terms of the Creative Commons Attribution Non-Commercial License (https://creativecommons.org/licenses/by-nc/4.0) which permits unrestricted non-commercial use, distribution, and reproduction in any medium, provided the original work is properly cited.
별된다. ${ }^{1)}$ 원인 및 발생 기전은 명확히 밝혀지지는 않았으나, 흡연, 알레르기, 특정 직업적 노출력(환경 유해인자) 등이 유발 인자로 생각되며, 재발이나 악성화에는 유두종 바이러스(HPV) 의 감염이 연관되어 있을 것으로 보고된다. ${ }^{1)}$ 반전성 유두종 의 치료는 병변의 완전한 절제이며, 이러한 이유로 1990년대 중 반까지는 외측 비절개술(lateral rhinotomy)을 통한 내측 상악 절제술, Denker씨 수술, 골성형 피판술(osteoplastic flap surgery, OPS) 등의 비외 접근법을 통한 광범위한 근치술이 최선의 표준 치료법으로 여겨졌으며, 평균 $20 \%$ 정도의 재발 률이 보고되어 있다. ${ }^{3)}$ 1992년 Waitz와 Wigand에 의해 처음 으로 내시경 수술로 반전성 유두종을 절제한 증례가 보고되 었으며, 비내시경을 이용한 보존적 수술의 재발률이 평균 $12 \%$ 로 더 낮음을 알 수 있다. ${ }^{4)}$ 이러한 이유로 비내시경을 이 
용한 비내 접근법이 새로운 표준 치료법으로 자리잡고 있다. 하지만, 종양의 침습범위, 원발부위에 따라 접근이 어려운 경 우, 단순 내시경하 절제술로는 제한이 있는 경우에는 외비접 근법의 적용 혹은 병행이 필요할 수 있다. 외비접근법 중 OPS 는 종양이 전두동을 광범위하게 침범하는 경우 시행되는데, 과거에는 일반적으로 양측 전두동을 개방하고 자가 지방조 직 등을 이용하여 폐쇄하는 방법이 이용되었으나 최근에는 일측 전두동만 개방하는 방법, 전두동을 폐쇄하지 않는 방법 이 소개되어 임상에서 활용되고 있다. ${ }^{5-7}$

저자들은 사골동 상벽에서 기원하여 전두동을 광범위하 게 침범한 반전성 유두종에 대해 비내 접근법과 전두동 천공
술을 병행하여 제거술을 시행했지만 전두동을 침범한 종양 을 완전히 제거하지 못한 42세 남자를 일측 $\mathrm{OPS}$ 를 통해 성공 적으로 치험하였기에 이를 문헌 고찰과 함께 보고하고자 한다.

\section{증 례}

42세 남자 환자가 후비루, 좌측 협부 통증을 동반하면서 수 년 전부터 서서히 진행된 좌측 비강의 코막힘을 주소로 내원 하였다. 4세 때 두부 외상을 입은 과거력이 있었으며, 이후 16 세 때 두개 결손에 대한 두개성형술(cranioplasty)을 시행받았다 고 하였다. 이후 특별한 합병증 없이 경과 관찰 중이었고, 그
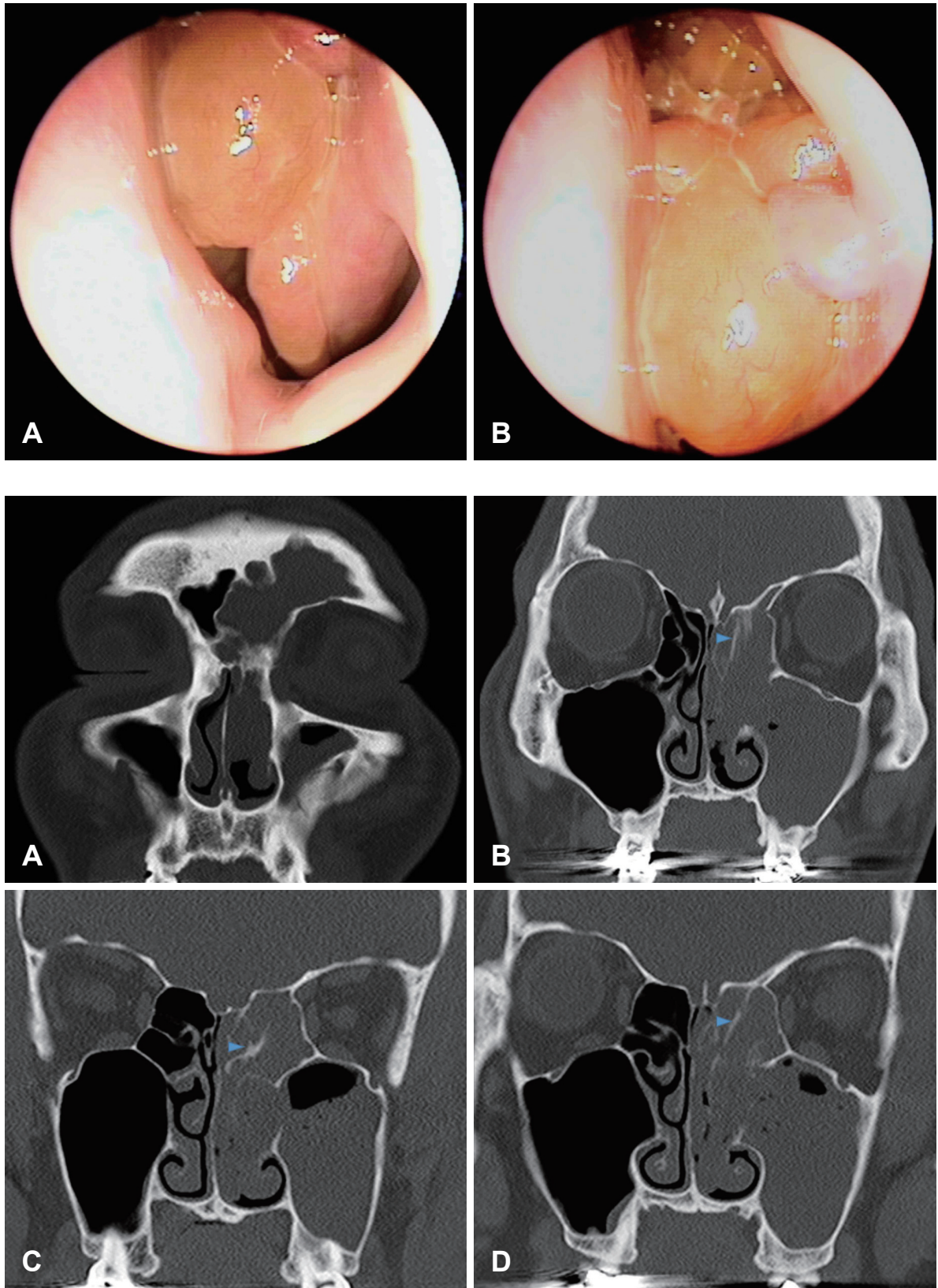
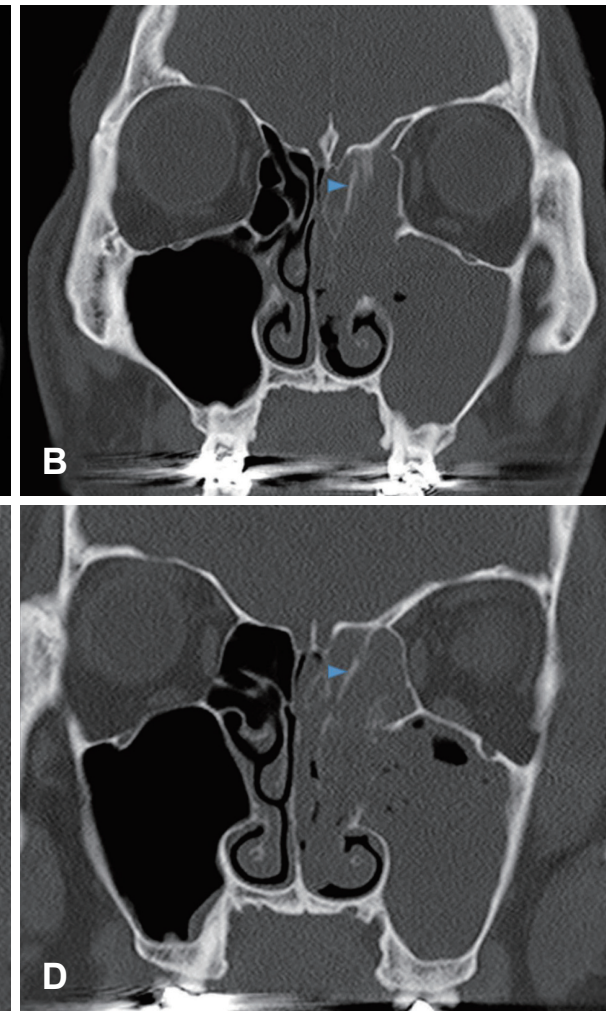

Fig. 1. Nasal endoscopic photographs. An overview of left nasal cavity (A). A close-up view of left middle meatus. A polypoid mass arising from the left middle meatus is observed $(B)$.

Fig. 2. A series of preoperative computerized tomography scans $(A-D)$. Left frontal, ethmoid and maxillary sinuses are filled with soft tissue density. Hypertrophic bony lesions indicating the origin of the tumor are shown from the ethmoidal roof through the superior meatus (blue arrowheads; B, C, and D). 
밖에 다른 기저질환은 없었다. 흡연 및 음주력은 없었으며, 가족력에서도 특이사항은 없었다. 비내시경 검사에서 좌측 중비도에 포도송이 모양의 폴립양 종괴가 관찰되었다(Fig. 1). 부비동 전산화단층촬영(computerized tomography, CT) 영 상에서 연조직 음영이 좌측 상악동, 사골동과 전두동에 걸쳐 관찰되었으며, 사골 천장에서 시작되어 상비도로 돌출되는 골 비후 병변이 관찰되었다(Fig. 2). 병변의 양상과 침습범위 등을 평가하기 위해 부비동 자기공명영상(magnetic resonance imaging, MRI) 검사를 시행하였으며, T2 강조영상에서 좌측 전 두동과 사골동의 대부분을 채우고 있는 대뇌양(cerebriform) 의 연조직 음영이 확인되었다. 이러한 병변은 조영증강 $\mathrm{T} 1$ 강 조영상에서 혼합성 증강 양상을 보였다. 좌측 상악동에서는 이차성 부비동염 소견이 관찰되었다(Fig. 3). 위의 소견을 바탕 으로 좌측 사골 천장에서 기원하여 전두동을 침범하는 반전 성 유두종 진단하에 비부비동 내시경 절제술을 계획하였으 며, 필요 시 전두동 천공술(frontal sinus trephination)을 병 행하기로 하였다. 수술 중 사골 천장부터 상비도에 이르는 골 비후 부위를 중심으로 사골동을 채우는 종양을 확인하였으
며 완전히 제거하였다. 하지만, 종양이 기원한 것으로 생각된 사골 천장의 종양을 제거한 후에도 잔여 종양이 전두와를 따라 전두동의 입구까지 360도에 걸쳐 광범위하게 퍼져 있는 소견이 확인되어 전두동 천공술을 시행하였다. 전두동 천공 술을 통해 종양 제거를 시도하였으나 전두동이 매우 함기화가 잘 되어 있는데다 종양이 전두동의 전벽, 후벽, 내측 및 외측 벽 전체에 걸쳐 퍼져 있어 정상 점막을 전혀 확인할 수가 없 었으며, 굴곡형 겸자 등 다양한 기구를 이용했음에도 종양의 완전 절제가 불가능하였다. 이에 추가적인 점막 손상을 막기 위해 수술을 중단하고 2차 수술을 계획하였다. 수술 후 조직 검사 결과 반전성 유두종으로 확인이 되었으며, 악성화 소견 은 관찰되지 않았다. 2차 수술로 OPS를 계획하였으며, 우측 의 전두동은 보존하고 환측인 좌측 전두동에 대해서만 시행 하기로 하였다. 2 차 수술은 1 차 수술 후 4주 뒤에 시행하였으 며 먼저 이개 전상부위에서 반대측 이개 전상부위까지 머리 카락선보다 약 $2 \mathrm{~cm}$ 뒤에 양측 관상절개를 가한 후, 필요 시 골막 피판을 사용하기 위해 모상건막하(subgaleal) 층으로 박리를 시행하였다(Fig. 4A). 하지만, 이전 전두동 천공술 부
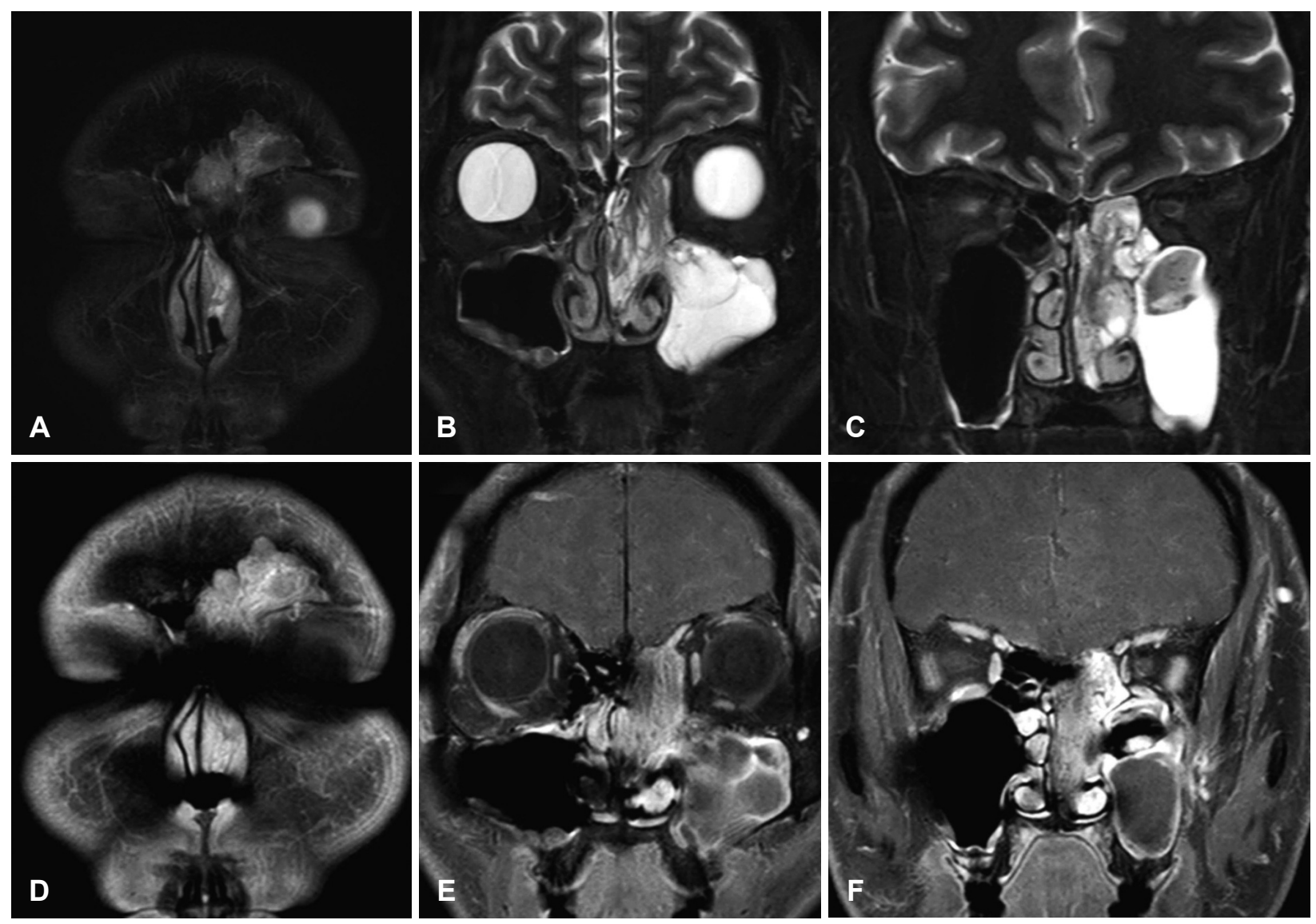

Fig. 3. A series of preoperative magnetic resonance images. A typical cerebriform, convoluted pattern of inverted papilloma is shown in the left ethmoid and frontal sinuses by T2-weighted coronal scans (A, B, and C). Tumors with mixed enhancement pattern are filling nearly the whole left ethmoid and frontal sinuses in T1-weighted coronal scans with gadolinium enhancement (D, E, and F). 
위의 유착으로 인해 박리가 어려웠으며, 무리한 박리 시 상안 와 신경혈관 다발(supraorbital neurovascular bundle)의 손상 이 우려되어 두개골막에 절개를 가한 뒤 두개골막하(subperi- cranial) 층으로 박리를 마무리하였다. 수술 전 촬영한 Caldwell X-ray 영상에서 의료영상저장전송시스템(picture archiving and communication system, PACS) 프로그램을 이용하여 전
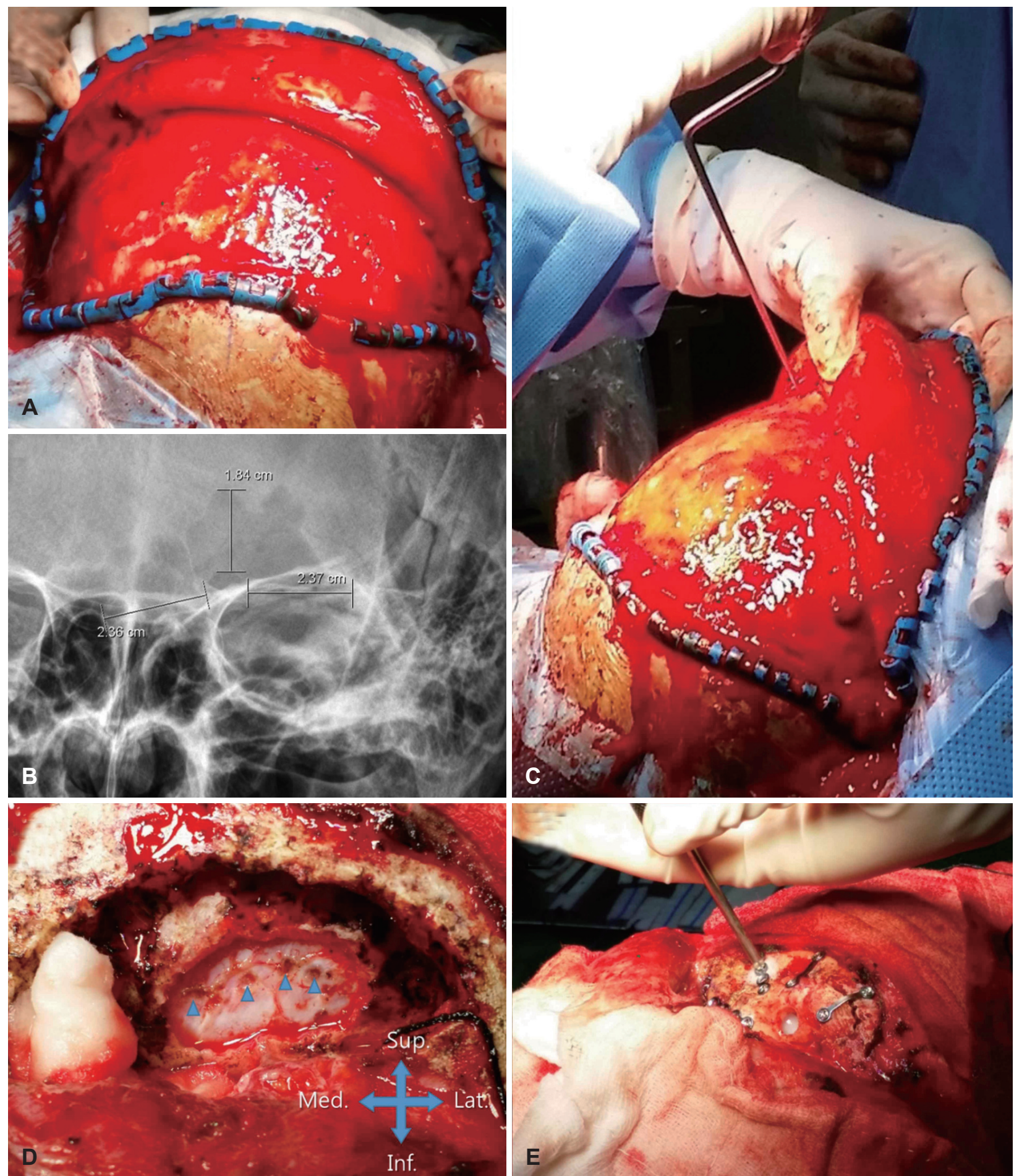

Fig. 4. Procedures of unilateral osteoplastic surgery. The bicoronal incision and galeal flap elevation (A). Measurement of the distances from the margin of the trephined hole on the anterior frontal table to the outer borders of the frontal sinus using the PACS program (B). Confirmation of the distance from the trephine hole to the boundary of the frontal sinus using a probe (C). Demonstration of multiple holes (blue arrowheads) on the dura mater after removal of the posterior frontal table (D). Fixation of the anterior frontal table using a couple of miniplates (E). PACS: picture archiving and communication system. Sup.: superior, Lat.: lateral, Med.: medial, Inf.: inferior. 
두동 천공술 부위로부터 좌측 전두동의 내측, 상측, 외측 경 계까지 거리를 측정하여 전두골 절골을 위한 정보로 활용하 였다(Fig. 4B). 안전한 절골을 위해 추가적으로 수술 중 $30^{\circ}$ 내시경을 천공 부위로 삽입한 뒤 투조법(transillumination) 을 이용하여 전두동의 윤곽을 확인하는 한편, 탐침을 삽입하 여 실제적인 거리를 확인함으로써 절골 시 의도하지 않은 두개 내 손상이 일어나지 않도록 하였다(Fig. 4C). 좌측 전두동의 경계를 따라 절골 후 골성형 피판을 젖히고 전두동 내부를 관찰하였을 때 종양이 전두동 점막 전체를 침범하고 있었으 며, 정상적인 점막은 관찰되지 않았다. 큐렛, 겸자, 드릴 등을 이용하여 골성형 피판의 내벽 및 전두동 내의 종양을 완전히 제거하였으며, 수술 중 시행한 동결절편검사에서는 반전성 유 두종이 확인되었고 악성화를 시사하는 소견은 없었다. 종양 제거 후 전두부리(frontal beak)를 드릴로 제거하여 전두동의 입구를 넓혀 주었으며 전두동은 폐쇄하지 않고 열어 두었다. 수술을 마치기 전에 전두동 후벽에서 뇌척수액 유출로 의심되 는 소견이 보여 전두동 후벽을 열어서 확인하였으며, 경막에 뚫 린 4개의 작은 구멍을 통해 뇌척수액이 유출되는 것이 확인되 어(Fig. 4D) 여러 겹의 fibrin-collagen patch(TachoComb ${ }^{\circledR}$; Nycomed, Linz, Austria)를 이용하여 경막 결손을 재건한 뒤 미니플레이트를 이용하여 골성형 피판을 고정하고 수술 을 마쳤다(Fig. 4E). 수술 후에는 뇌척수액 유출 방지를 위해 1 주일간 요추배액을 시행하였다. 환자는 외래 추적 관찰 과 정에서 전두동 입구부의 협착이 발생하여 비내시경 검사로 전두동 전체를 확인할 수는 없었다. 하지만, 조영증강 CT에 서 수술 후 2 년째까지 종양의 재발 소견은 없었고 전두동의 함 기화도 유지되었다(Fig. 5). 또한, 관상절개에 따른 두피 반흔
이외에 뇌척수액 유출 등의 특별한 합병증도 없었다.

\section{고 찰}

다양한 각도의 내시경과 수술 기구의 발달로 인해 과거에 는 접근하기 어려웠던 후사골동, 접형동 등의 병변을 정확하 게 확인하고 수술을 할 수 있게 되어 최근 비부비동 반전성 유두종의 수술은 내시경을 이용한 비내 접근법 수술이 주된 치료법으로 자리잡게 되었다. 또한, 비내시경을 이용한 비내 접근법은 술 후 합병증이 비외 접근법에 비해 적고, 정상 점 막 및 구조물을 최대한 보존함으로써 비강 내 생리적 기능을 유지할 수 있도록 해주는 등 장점도 있다. 또한, endoscopic modified Lothrop procedure 등 수술법의 발달로 과거에는 비외 접근법이 필요했던 병변을 비내 접근법만으로 치료를 할 수 있게 되었으며, 비외 접근법을 병행하더라도 전두동 천 공술과 같이 최소 침습적인 방법만을 병행함으로써 치료할 수 있는 경우도 많아졌다. ${ }^{8,9)}$ 하지만, 종양이 단순히 전두동 내로 자라난 경우가 아니라 정상 점막을 따라 광범위하게 침 범하는 경우 비내 접근법만으로는 완전한 제거가 어려우며, 특히 전두동의 함기화가 잘 되어 있는 경우에는 특히 그러하 다. ${ }^{10)}$ 이러한 경우 미니 골성형 피판술(mini-OPS)이나 OPS와 같이 보다 침습적인 접근법의 사용이 필요하다. 반구 또는 양 측 관상절개를 통한 $\mathrm{OPS}$ 는 전두동의 접근을 용이하게 하여 병변의 완전한 제거를 하는 데 효과적인 술식이지만, 수술 부위(forehead)의 무감각, 탈모증, 절개부위 및 안면신경의 전두근 가지의 마비 등 수술 후 합병증의 가능성이 있다. ${ }^{11)}$ 이러한 합병증을 줄이기 위해 확장된 Lynch 절개법(extended
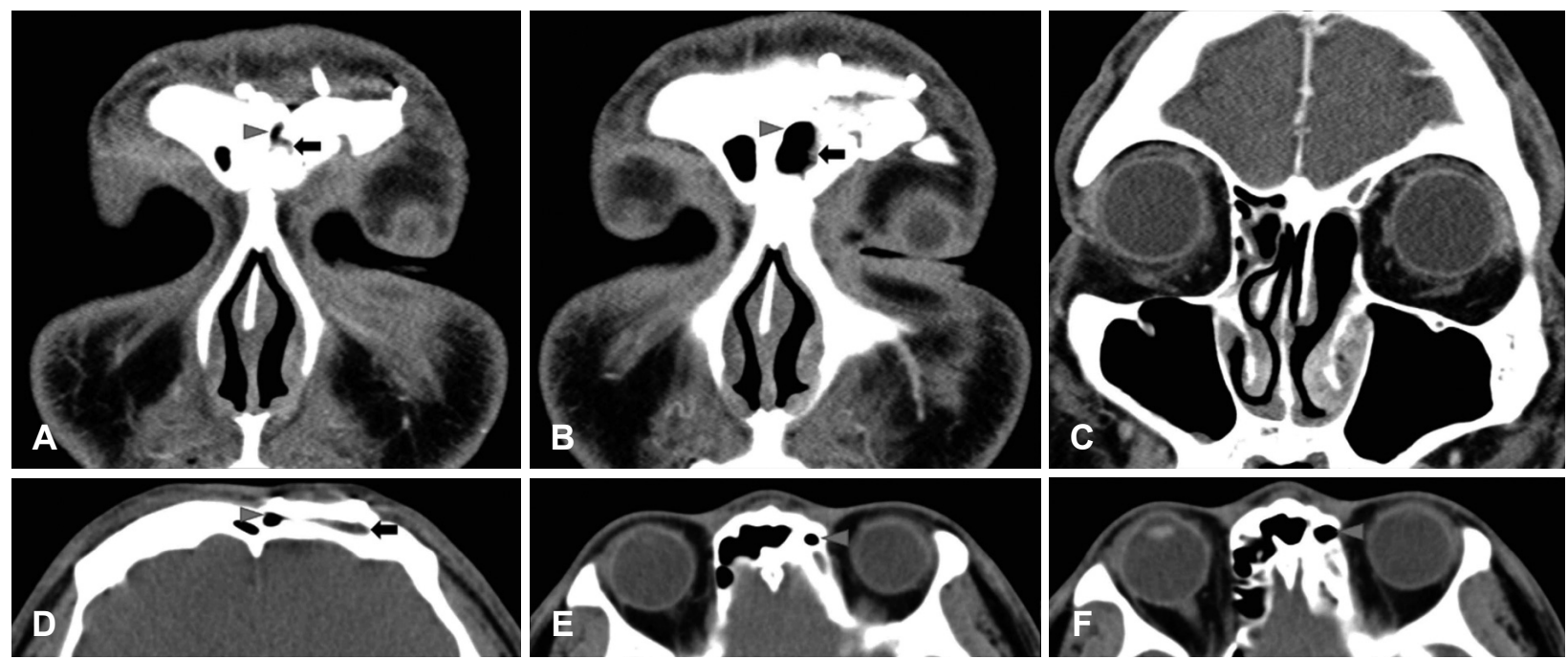

Fig. 5. Postoperative enhanced computed tomography scans obtained at 2 years after the surgery. Left frontal sinus remains pneumatized (gray arrowheads; A, B, D, E, and F) and only non-enhanced soft tissues with no evidence of recurred tumor are visible within the left frontal sinus (black arrows; $A, B$, and D), which indicate the reconstructed defect site of dura. There was no evidence of recur-rence in ethmoidal cavities, either (C). 
Lynch incision)을 이용한 mini-OPS가 소개되었다. ${ }^{11)} \mathrm{Mini}^{-}$ OPS는 눈썹의 내측 아래쪽 방향으로 절개를 한 후, 이에 수 직인 절개를 비근점(nasion) 방향으로 추가하여 전두동 병변 에 접근하는 방법을 이용한다. 미니 mini-OPS는 절개 시 상 안와 신경혈관 다발의 손상 가능성이 있고, 전두와 부위 폐 쇄로 인한 부비동염의 발생 가능성이 있지만, OPS에 비해 상 대적으로 수술 후 회복기간이 짧고, 덜 침습적인 장점이 있 다. ${ }^{11)}$ 과거에는 OPS 후 자가 지방조직, 근육조직 혹은 수산화 인회석(hydroxyapatite) 등의 이식물이나 두개골막 피판 등을 이용하여 전두동 폐쇄를 시행하는 것이 일반적이었다. ${ }^{12,13)}$ 전 두동 폐쇄가 성공적으로 이루어지면 지방조직은 섬유조직으 로 대체되는데, 전두동 폐쇄가 성공적으로 이루어지지 못할 경우 이식한 지방조직과 점막의 재흡수가 일어난다. 이러한 실 패의 가장 큰 원인은 전두동 점막의 불완전한 제거 때문이 며, 그 결과 시간의 흐름에 따라 자가 지방조직이 흡수되면서 두부 함몰이 나타나기도 하며, 술 후 감염 등의 합병증이 나타 난다. ${ }^{5)}$ 또한, 지연적으로 점액낭(mucocele), 골수염(osteomyelitis) 등이 발생하기도 한다. 그리고 이러한 지방조직, 섬유 화, 점막의 변형 등이 영상 검사(CT 또는 $\mathrm{MRI})$ 에서 종양과 구분이 쉽지 않기 때문에 종양 재발의 조기 발견을 어렵게 하 는 단점 또한 있다. ${ }^{5)}$ 이를 극복하기 위해 OPS를 시행하면서 전두동을 폐쇄하지 않는 방법이 소개되고 시도되어 왔으며, 전두동 폐쇄를 시행하지 않을 경우 수술 후 두부 함몰의 발 생, 지방을 절제한 복부 등에 흥터 발생 등의 단점이 발생하지 않아 미용적으로 더 우수한 결과를 보인다. 또한, 전두동 자 연공을 유지하기 때문에 점액섬모 운동을 통한 자연 배농이 이루어지므로 부비동염 등의 합병증 발생 가능성도 낮은 장 점이 있다. 추가적으로 외래에서 내시경상으로 추적 관찰을 하기 용이하기 때문에 최근에는 전두동 폐쇄를 시행하지 않 는 방법이 보편화되고 있다.

또한, 과거에 OPS는 양측 전두동에 대해 동시에 시행되었 는데, 최근에는 일측 골성형 피판술(unilateral OPS, uOPS) 방식이 소개되어 건측의 전두동을 보존하는 것이 가능해졌 다.) $\mathrm{uOPS}$ 는 반구 또는 양측 관상절개로 시작하여 피판을 들어 올리는 과정까지는 일반적인 OPS와 같으며 이후, 항법 영상장치 등을 이용하여 전두동의 경계를 확인하여 골성형 피판을 한쪽 전두동 부분만 들어 올려서 건측의 전두동을 보존하는 방법이다.) 이러한 OPS 수술법의 변천에 기반하여 저자들은 일측 전두동을 광범위하게 침범한 반전성 유두종 을 보이는 상기 환자에서 전두동을 폐쇄하지 않으면서 환측 의 전두동에 대해서만 $\mathrm{uOPS}$ 를 시행하는 것이 완전한 종양의 절제를 가능하게 하면서도 건측의 전두동을 보존하는 이상적 인 수술법으로 판단하였다. 저자들은 $\mathrm{uOPS}$ 를 통해 잔존 종
양을 완전히 제거할 수 있었으며, 전두동 폐쇄를 하지 않아 술 후에 전두동의 함기화가 유지되는 것도 확인하였다(Fig. 5). 하지만, 외래 추적 관찰 과정에서 전두동 입구부의 협착이 진행되어 비내시경 검사를 이용한 추적 관찰은 할 수 없었 다. 이는 전두동 입구의 협착을 막는 데 도움이 된다고 알려 진 스텐트 삽입이나 mitomycin $\mathrm{C}$ 의 도포와 같은 방법을 적 극적으로 사용하였다면 예방할 수도 있었을 것이다. ${ }^{14,15}$ 전두 동 폐쇄를 하지 않으면서 uOPS를 시행하는 경우 전두동 입구 의 협착을 막기 위해 전두부리뿐만 아니라 비골을 포함하여 골부를 최대한 제거하여 전두동 입구를 넓히는 한편 mitomycin C를 도포하는 등 협착을 방지하기 위한 여러 가지 방 법을 병행하는 것이 필요할 것으로 생각된다.

한편, OPS 수술 시 골성형 피판을 만드는 절골 과정에서 두개내 손상을 피하기 위해 과거에는 6피트 거리에서 찍은 Caldwell X-ray 필름을 템플릿으로 사용을 했었는데 현재 는 PACS 시스템이 보편화되어 필름 인화 장비를 갖추지 않 은 병원이 많다. 이를 대신하여 최근에 많이 보편화된 항법 영상장치를 이용하면 도움을 얻을 수 있다. 저자들은 1 차 수 술 때 생긴 전두동 천공 부위를 기준으로 하여 PACS 시스템 의 프로그램을 이용하여 Caldwell 영상에서 거리를 측정하 는 한편 수술 중 탐침자를 이용하여 천공 부위를 통해 직접 전두동 벽까지의 거리를 측정하였다. 이를 응용하면 방사선 비투과 물질을 전두동 부위 피부에 부착한 뒤 Caldwell 영 상을 촬영하여 PACS 시스템 내에서 전두동의 가장자리까지 거리를 측정하는 방법을 사용할 수도 있을 것이다. 이 환자 에서처럼 전두동 천공술 이후 2 차 수술로 $\mathrm{uOPS}$ 를 시행하는 경우 전두동 천공 부위를 통한 투조법도 도움이 될 수 있으나 종양이 전두동 내를 상당부분 채우고 있는 경우에는 정확한 측정이 어려울 수 있음을 고려해야 한다. 또한, 이 환자에서 수술 시 전두동 후벽의 뚜렷한 골결손이 없었음에도 불구하 고 뇌척수액 유출이 확인되었는데, 이는 드릴링 과정에서 눈에 보이지 않는 미세한 골결손이 생기고 그로 인해 인접한 뇌경 막이 찢어지면서 발생한 것으로 보인다. 전두동 후벽에 대한 드릴링은 매우 조심스럽게 진행해야 할 것으로 생각된다.

요컨대 내시경 수술의 발달에 따라 비부비동 반전성 유두종 의 치료는 내시경을 이용한 비내 접근법이 표준 치료법이 되 었다. 하지만, 본 증례와 같이 반전성 유두종이 일측성으로 전 두동 점막을 따라 광범위하게 퍼져 있는 경우 전두동 폐쇄를 하지 않는 $\mathrm{uOPS}$ 는 특별한 합병증 없이 수술 후 추적 관찰을 용이하게 하는 좋은 수술법으로 생각된다.

\section{REFERENCES}

1) Lisan Q, Laccourreye O, Bonfils P. Sinonasal inverted papilloma: 
from diagnosis to treatment. Eur Ann Otorhinolaryngol Head Neck Dis 2016;133(5):337-41.

2) Min IK, Koo BS, Park CH, Kim AY, Park SW, Rha KS. Inverted papilloma of the nose and paranasal sinusesan analysis of 102 cases. Korean J Otolaryngol Head Neck Surg 2003;46(8):659-64.

3) Peng P, Har-El G. Management of inverted papillomas of the nose and paranasal sinuses. Am J Otolaryngol 2006;27(4):233-7.

4) Busquets JM, Hwang PH. Endoscopic resection of sinonasal inverted papilloma: a meta-analysis. Otolaryngol Head Neck Surg 2006;134 (3):476-82.

5) Correa AJ, Duncavage JA, Fortune DS, Reinisch L. Osteoplastic flap for obliteration of the frontal sinus: five years' experience. Otolaryngol Head Neck Surg 1999;121(6):731-5.

6) Welch KC. Osteoplastic approach to the frontal sinus, unilateral. Oper Tech Otolaryngol Head Neck Surg 2010;21(2):138-42.

7) Melroy CT, Dubin MG, Senior BA. Management of benign frontal sinus tumors with osteoplastic flap without obliteration. Oper Tech Otolaryngol Head Neck Surg 2004;15(1):16-22.

8) Shirazi MA, Silver AL, Stankiewicz JA. Surgical outcomes following the endoscopic modified Lothrop procedure. Laryngoscope 2007;117 (5):765-9.

9) Nicolai P, Tomenzoli D, Lombardi D, Maroldi R. Different endoscopic options in the treatment of inverted papilloma. Oper Tech Otolaryngol Head Neck Surg 2006;17(2):80-6.

10) Yoon BN, Lee JE, Lee HS, Cho KS, Roh HJ. The surgical approach for removal of inverted papilloma originating from the frontal sinus. Korean J Otorhinolaryngol-Head Neck Surg 2008;51(9):800-4.

11) Salamone FN, Tami TA. Access to the frontal sinus with a mini osteoplastic flap. Oper Tech Otolaryngol Head Neck Surg 2004;15(1): 53-6.

12) Taghizadeh F, Krömer A, Laedrach K. Evaluation of hydroxyapatite cement for frontal sinus obliteration after mucocele resection. Arch Facial Plast Surg 2006;8(6):416-22.

13) Oztürk K, Duran M, Arbağ H, Keleş B, Kara M, Uyar Y. [Frontal sinus obliteration with pericranial-subgaleal flap]. Kulak Burun Bogaz Ihtis Derg 2010;20(1):13-7.

14) Benoit CM, Duncavage JA. Combined external and endoscopic frontal sinusotomy with stent placement: a retrospective review. Laryngoscope 2001;111(7):1246-9.

15) Chan KO, Gervais M, Tsaparas Y, Genoway KA, Manarey C, Javer AR. Effectiveness of intraoperative mitomycin $\mathrm{C}$ in maintaining the patency of a frontal sinusotomy: a preliminary report of a doubleblind randomized placebo-controlled trial. Am J Rhinol 2006;20(3): 295-9. 